\title{
Sin cultura no hay educación. Entrevista a José Gimeno Sacristán
}

\section{Without culture there is no education. Interview with José Gimeno Sacristán}

Ester Caparrós Martín* y J. Eduardo Sierra Nieto**

Recibido: 21 de julio de 2020 Aceptado: 22 de julio de 2020 Publicado: 31 de julio de 2020

To cite this article: Caparrós, E. y Sierra, J. E. (2020). Sin cultura no hay educación. Entrevista a José Gimeno Sacristán. Márgenes, Revista de Educación de la Universidad de Málaga, 1 (2), 209-213

DOI: http://dx.doi.org/10.24310/mgnmar.v1i2.9974

URL: https://www.youtube.com/watch?v=ySkzpOls3cl\&feature=youtu.be

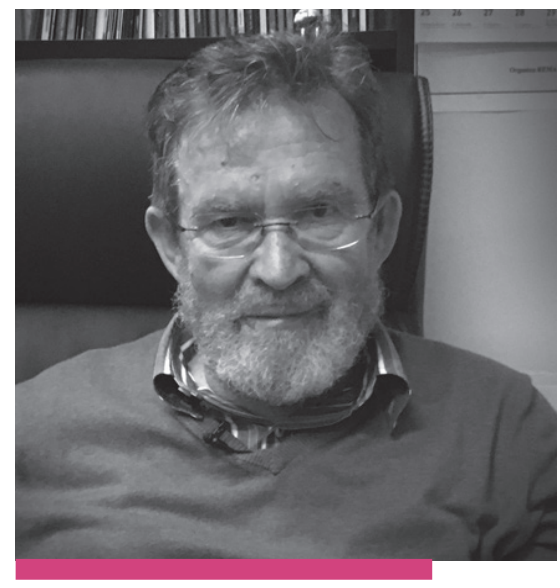

José Gimeno Sacristán
Palabras clave: cultura; currículum; pedagogía; Transición Española; universidad

Keywords: culture; curriculum; pedagogy; Spanish Transition; university

\section{BIOGRAFÍA}

José Gimeno Sacristán es Catedrático jubilado de Didáctica y Organización Escolar en la Universidad de Valencia. Se trata de uno de los pedagogos más reconocidos de nuestro país y, sin duda, una de las figuras más influyentes en el ámbito educativo en la España contemporánea. Su trayectoria docente e investigadora le ha llevado a ser profesor en la Universidad Complutense de Madrid y en la de Salamanca; además, ha sido profesor visitante y ponente en muchas otras universidades españolas y extranjeras. Durante los años ochenta, junto a otros nombres relevantes, fue asesor del Ministro de Educación del primer gobierno Socialista, José Ma Maravall.

En 2010 fue nombrado Doctor Honoris Causa por la Universidad de Málaga, recibiendo al año siguiente el mismo reconocimiento por la Universidad de San Luis, en Argentina.
*Ester Caparrós Martín

http://orcid.org/0000-0003-1700-3577

Departamento de Didáctica y Organización Escolar, Universidad de Málaga ester.caparros@uma.es
${ }^{* *}$. Eduardo Sierra Nieto http://orcid.org/0000-0002-9925-1656

Departamento de Teoría e Historia de la Educación y MIDE, Universidad de Málaga esierra@uma.es 
Como narraba el profesor Pérez Gómez en su lauda$t_{i o}{ }^{1}$, Gimeno "ha ejercido una marcada influencia en el pensamiento pedagógico español, primero por la relevancia científica de sus aportaciones, segundo por la oportunidad del momento y tercero por el compromiso con el devenir cotidiano”.

Entre sus obras publicadas, destacamos: La Pedagogía por objetivos. Obsesión por la eficacia (1982); El currículum, una reflexión sobre la práctica (1988); Poderes inestables en educación (1998) y Saberes e incertidumbre sobre el currículum (2010), todas ellas en Morata, su editorial de referencia. Junto a Ángel Pérez coordinó dos obras que significaron una importante apertura a la literatura que, durante las décadas de los 80 y 90, destacaba fuera de nuestras fronteras: La enseñanza, su teoría y su práctica (1983), en Akal; y Comprender y transformar la enseñanza (1991), nuevamente en Morata. Ambas obras, como nos cuenta en la entrevista, tuvieron una marcada influencia en el cambio de paradigma acontecido con el paso del estudio del conductismo al estudio del pensamiento docente.

Para Márgenes, entrevistar a José Gimeno ha supuesto tener la posibilidad de conversar con una de las figuras más prestigiosas de la pedagogía y empaparnos de todo su saber y conocimiento. En la entrevista, el autor sostiene un discurso trufado de anécdotas personales a través de las cuales es posible recomponer su trayectoria académica, a la vez que podemos entender algo mejor el trasfondo social, político y científico de la transición española y las décadas posteriores.

El autor nos acerca también a su visión sobre el significado de la educación, la cultura y la pedagogía, hoy. Deteniéndose, más concretamente, en uno de los temas que más focos acapara en educación: el currículum escolar. Para Gimeno el currículum no es algo fijo, sino interpretado por el profesorado, en una explícita referencia al pensamiento de Lawrence Stenhouse. "El currículum ha tenido la virtud de polemizar sobre la realidad intelectual", sostiene Gimeno, refiriéndose a que éste se hace en las escuelas, de modo que, lo que aborda

\section{"El currículum ha tenido la virtud de polemizar sobre la realidad intelectual."}

1 El texto completo está disponible aquí. 


\section{"Hay contenidos, desde luego, que están concebidos como si fueran de la Edad Media"}

y trabaja, es el análisis de lo escolar: "abriendo la discusión en torno a la reflexión sobre la teoría y la práctica”.

Asimismo, nos explica la importancia de pensar en los contenidos como materia prima de la educación, comentando que, al parcializarlos por materias, no contribuimos a la verdadera conformación del pensamiento. "Hay contenidos, desde luego, que están concebidos como si fueran de la Edad Media”, indica. A lo que añadirá que estos han de ser propuestos por quien "tiene legitimidad y poder para hacerlo, o los impondrá el mercado”.

En definitiva, Gimeno nos permite reabrir viejos - aunque vigentes - debates sobre la pedagogía, y haciendo mención a las palabras de DEWEY, nos explica que su función no es otra que favorecer que el conocimiento se convierta en experiencia.

\section{BIOGRAPHY}

José Gimeno Sacristán is a retired Professor of Didactics and School Organization at the University of Valencia. He is one of the most recognized pedagogues in our country and, without a doubt, one of the most influential figures in the educational field in Spain nowadays. His teaching and research career has led him to become a Professor at the Complutense University of Madrid and the University of Salamanca. In addition, he has been a visiting professor and speaker at many other Spanish and foreign universities. During the 80s, along with other relevant names, he was an advisor to the Minister of Education of the first Socialist government, José Ma Maravall.

In 2010 he was named Doctor Honoris Causa by the University of Malaga, receiving the same recognition the following year by the National University of San Luis, in Argentina. As Professor Pérez Gómez narrated in his laudatio ${ }^{2}$, Gimeno "has exerted a marked influence on the Spanish pedagogical thought, first because of the scientific relevance of his contributions, second be-

The complete text is available here. 


\section{E N T R E V I S T A S}

cause of the opportunity of the moment and third because of his commitment to the everyday progression."

Among his published works, we highlight: Pedagogy by objectives. Obsession with effectiveness [La pedagogía por objetivos. Obsesión por la eficacia] (1982); The curriculum, a reflection on practice [El currículum, una reflexión sobre la práctica ] (1988); Unstable Powers in Education [Poderes inestables en educación] (1998) and Knowledge and Uncertainty about the Curriculum [Saberes e incertidumbre sobre el currículum] (2010), all of them published in Morata, his reference publisher. Together with Ángel Pérez, he coordinated two works that meant an important opening to literature that, during the 80s and 90s, stood out outside our borders: Teaching, its theory and practice [La enseñanza, su teoría y su práctica ] (1983), in Akal; and Understanding and transforming teaching [Comprender y transformar la enseñanza ] (1991), again in Morata. Both works, as he tells us in the interview, had a marked influence on the change of paradigm that occurred with the shift from the study of behaviorism to the study of teacher reflection.

For Márgenes, interviewing José Gimeno has meant having the opportunity to talk with one of the most prestigious figures in pedagogy and soak up all his knowledge. In the interview, the author keeps a speech filled of personal anecdotes through which it is possible to rebuild his academic career, while at the same time we can better understand the social, political and scientific background of the Spanish Transition and the subsequent decades.

The author also brings us closer to his vision of the meaning of education, culture and pedagogy today. Stopping, particularly, on one of the most highlighted topics in education: the school curriculum. For Gimeno, the curriculum is not something fixed, but interpreted by the teachers, in an explicit reference to the thought of Lawrence Stenhouse. "The curriculum has had the virtue of starting an argument on intellectual reality", says Gimeno, referring to the fact that it is done in schools. Therefore, what he addresses and works on is the analysis of school matters: "opening the discussion around reflection on theory and practice”.

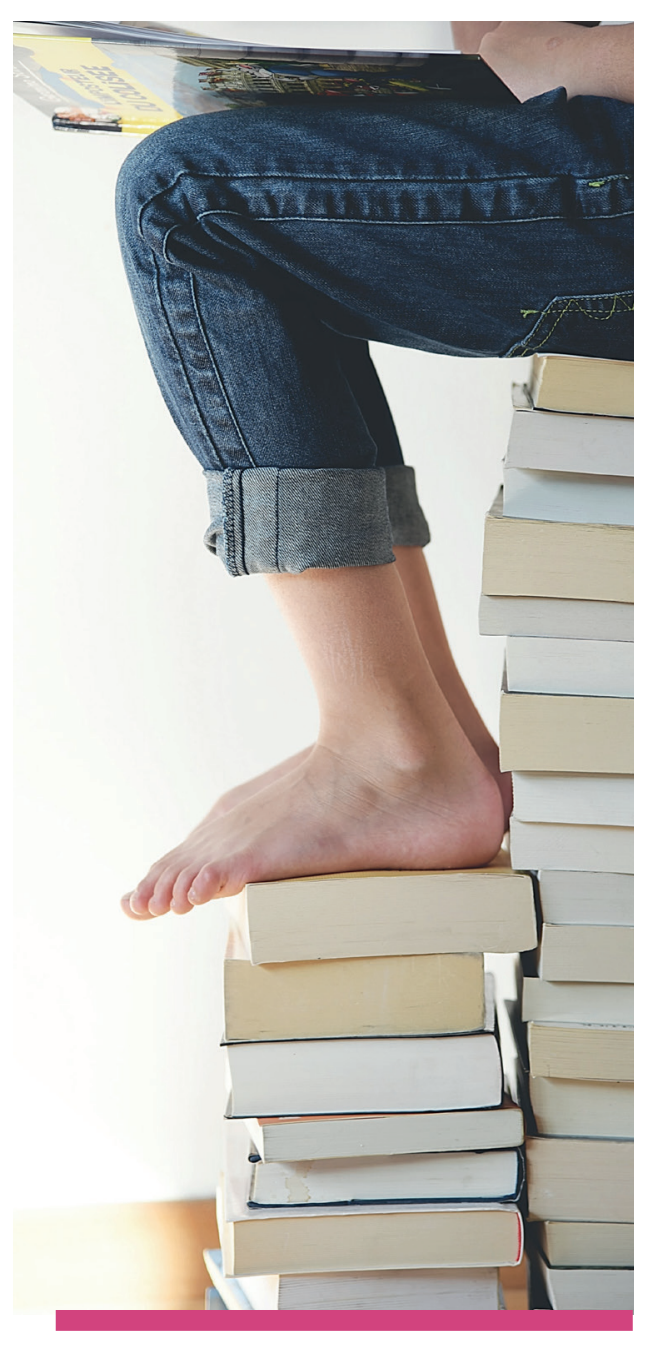

Photo by Gaelle Marcel on Unsplash 


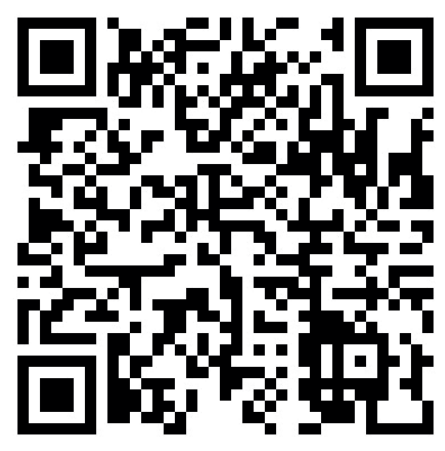

Likewise, he explains the importance of thinking about content as raw material for education, commenting that, by dividing it into subjects, we do not contribute to the true conformation of thought. "There are contents, of course, that are conceived as if they were from the Middle Ages," he says. To which he will add that these must be proposed by those who "have the legitimacy and power to do so, otherwise the market will impose them.”

In short, Gimeno allows us to reopen old -although current- debates about pedagogy, and mentioning DEWEY's words, he explains that his role is none other than to favor that knowledge becomes experience. 